with Ochromonas and with Bact. coli. The Ochromonas technique was adjudged capable of measuring cyanocobalamin specifically in a variety of crude extracts, some known to contain vitamin $\mathrm{B}_{12}$-like compounds active for Bact. coli.

I wish to thank Drs E. S. Holdsworth and S. K. Kon for helpful interest in this work.

\title{
REFERENCES
}

Bessell, C. J., Harrison, E. \& Lees, K. A. (1950). Chem. छ Ind. p. 56r.

Burkholder, P. R. (195I). Science, 114, 459.

Coates, M. E., Ford, J. E., Harrison, G. F., Kon, S. K. \& Porter, J. W. G. (1953). Brit. F. Nutr. 7, 319.

Cuthbertson, W. F. J., Pegler, H. F. \& Lloyd, J. T. (195 I). Analyst, 76, r33.

Ford, J. E. (1952). Brit. F. Nutr. 6, 324.

Ford, J. E. (1953). Nature, Lond., I71, 149.

Ford, J. E., Holdsworth, E. S., Kon, S. K. \& Porter, J. W. G. (1953). Nature, Lond., r71, I50.

Ford, J. E., Holdsworth, E. S. \& Porter, J. W. G. (1953). Proc. Nutr. Soc. 12, xi.

Gregory, M. E., Ford, J. E. \& Kon, S. K. (1952). Biochem. F. 5I, xxix.

Hamilton, L. D., Hutner, S. H. \& Provasoli, L. (1952). Analyst, 77, 6 r8.

Harrison, E., Lees, K. A. \& Wood, F. (1951). Analyst, 76, 696.

Holdsworth, E. S. (1953). Nature, Lond., r71, 148.

Hutner, S. H., Provasoli, L. \& Filfus, J. (1953). Ann. N.Y. Acad. Sci. 55, 852.

Skeggs, H. R., Nepple, H. M., Valentik, K. A., Huff, J. W. \& Wright, L. D. (r950). F. biol. Chem. 184,211 .

\section{Antibiotics in the Diet of the Fattening Pig}

\author{
By R. S. BARBER, R. BRAUDE, S. K. KON AND K. G. MITCHELL \\ National Institute for Research in Dairying, University of Reading
}

(Received 2 March I953)

The first indication by Stokstad, Jukes, Pierce, Page \& Franklin (1949) that the antibiotic, aureomycin, stimulated growth in chicks led to numerous experiments on the effects of adding antibiotics or fermentation residues containing antibiotics to the diet of chicks, pigs and other animals. Braude, Wallace \& Cunha (1953), reviewing the greater part of this work with pigs up to the beginning of $195^{2}$, emphasized the complexity of the subject and indicated some of the many and varied factors that appear to have influenced results. From the large amount of evidence reviewed, the authors did not feel justified in drawing any other conclusion than that under some conditions of husbandry some of the antibiotics exert a growth-promoting effect on pigs.

Work published subsequently has, in the main, served to confirm this conclusion, and it is not proposed to present in this paper a review of the further extensive literature on the subject, especially as our review on antibiotics as growth promoters, dealing with all classes of livestock, has just appeared (Braude, Kon \& Porter, 1953). In this paper we describe the results of four separate experiments on the effects of adding antibiotics to the diet of fattening pigs. Results of Exps. I and 2 have been briefly summarized in preliminary publications (Braude, Kon \& Mitchell, I95I; Barber, Braude, Kon \& Mitchell, I952). 


\section{EXPERIMENTAL}

The purpose of the four experiments was to ascertain whether an improvement in the rate of growth and efficiency of food utilization could be obtained by supplementing diets of different composition with aureomycin, aureomycin residues or procaine penicillin. In some instances the procaine penicillin was fed along with a streptomycin residue known to contain vitamin $\mathrm{B}_{12}$ but no antibiotic, to make the combination similar to the aureomycin residue, which contained both factors.

All-meal feeding was used in the first three experiments and the Lehmann method of feeding, employing bulky foods, in the fourth. Effects with all-vegetable diets were compared with those obtained from diets containing animal protein. The individualfeeding method was used in all four tests. In each there were six treatments with at least six replicates; the numbers involved are shown in Tables $2-5$, which give the results of each test. Home-bred Large White weaners were used for each test; they were balanced as far as possible for sex, initial weight and litter origin.

In the first experiment a single experimental block consisted of five litter-mates, later increased to six, and the experimental treatments were allocated at random to the pigs forming the unit: those of each unit were housed together in one pen.

In Exps. 2-4 all the pigs receiving the same treatment were housed in the same pen, and the six litter-mate members of the experimental unit were distributed at random to the six pens allocated for the test. Each of the pens contained six small compartments into which the pigs were shut for individual feeding twice daily.

The compositions of the meal mixtures used in the four experiments are given in Table I. These mixtures were all prepared in our piggery. To minimize any possible

\section{Table I. Percentage composition of the diets}

\begin{tabular}{|c|c|c|c|c|c|}
\hline Ingredient & $\begin{array}{c}\text { Diet A } \\
\text { Exps. 1, 2, 3 }\end{array}$ & $\begin{array}{c}\text { Diet B } \\
\text { Exps. 2, 3 }\end{array}$ & $\begin{array}{l}\text { Diet C } \\
\text { Exp. } 3\end{array}$ & $\begin{array}{l}\text { Diet D* } \\
\text { Exp. } 4\end{array}$ & $\begin{array}{l}\text { Diet E } \\
\text { Exp. } 4\end{array}$ \\
\hline Barley meal & 35 & $3^{1}$ & 30 & 30 & 30 \\
\hline Fine miller's offals & 40 & 33 & 33 & 34.5 & 33 \\
\hline Flaked maize & 15 & 15 & 14 & 10 & 10 \\
\hline White fish meal & I0 & - & 一 & $2 \cdot 5$ & 一 \\
\hline Decorticated groundnut meal & 一 & I I & 21 & 9 & $12 \cdot 5$ \\
\hline Bean meal & 一 & 6 & - & - & - \\
\hline Sunflower meal & - & 2 & - & - & - \\
\hline Dried lucerne meal & - & - & - & 5 & 5 \\
\hline Coconut meal & 一 & - & - & 6 & 6 \\
\hline Limestone & - & $\mathrm{I} \cdot 5$ & $1 \cdot 5$ & 0.5 & - \\
\hline Steamed bone flour & 一 & - . & 一 & 2 & 3 \\
\hline Salt & - & 0.5 & 0.5 & 0.5 & 0.5 \\
\hline Crude protein $(\%)$ & $17 \cdot 1$ & $17 \cdot 3$ & $19 \cdot 9$ & $17 \cdot 8$ & $17 \cdot 8$ \\
\hline
\end{tabular}

I oz. of cod-liver oil per pig was added once weekly directly into the troughs.

* The content and quality of the protein in meal D was representative of the minimum standard laid down at the time for proprietary sow and weaner meals.

loss of antibiotic activity on storage, batches of meal sufficient to last for about 3 weeks were mixed at a time. The small quantities of the supplements were first gradually pre-mixed into ro lb. of barley meal and this was then mixed thoroughly with the rest of the ingredients in a large mechanical mixer. 
In the first three experiments in which all-meal feeding was used, the meal was given twice daily as a wet mash, approximately $3 \mathrm{lb}$. of water being added to each pound of meal. The quantity of meal given was based on live weight and the scale for fattening pigs described by Braude \& Mitchell (I950-r). In the fourth test $3 \mathrm{lb}$. of meal and I gal. of water were given daily to each pig with fodder beet to appetite. In this experiment the pigs were fed twice daily for the first II weeks, and thereafter three times a day.

In the first experiment the diet used was a good pig ration containing adequate amounts of animal protein, as normally recommended for fattening pigs in this country.

In Exp. 2, diets containing food of vegetable origin only were used with the antibiotics. Most of the American investigations dealing with the growth-promoting effect of antibiotics in pigs were done with purely vegetable diets, and it was therefore considered that similar diets should be tested under our conditions.

In Exp. 3 one of the antibiotics (penicillin) was tested again with the diets employed in Exps. I and 2, and also with a vegetable mixture containing only decorticated groundnut meal as the protein supplement and more total crude protein than the other mixtures. The inclusion of this meal mixture in the experiment was based on a report by Woodman \& Evans (195I) that pigs given an all-vegetable meal of this type grew at a similar rate to pigs fed on a diet containing an optimum amount of fish meal. In Exp. 4 diets were used containing no, or very little $(2.5 \%)$, animal protein in conjunction with the Lehmann system of feeding. Fodder beet was used as bulky food, because of the satisfactory results obtained previously in our piggery with such a combination (Braude \& Mitchell, 1949-50). The varieties of fodder beet were Pajbjerg Rex and Hunsballe, the latter being fed only during the last 6 weeks of the test.

At the end of Exps. 2, 3 and 4 measurements were taken for assessment of carcass quality by McMeekan's (1940) method. The carcasses were also graded by expert commercial graders.

In addition to the main aspects under investigation a number of side issues received our attention; the matters investigated are described later in this paper.

\section{RESULTS}

Exp. I. All the pigs in this experiment were very thrifty, growing at a consistent rate and remaining in excellent health throughout. In Table 2 the mean values for live-weight gain and efficiency of food utilization during the 18 weeks' experimental period are given, with their standard errors.

These results indicate that the pigs receiving an antibiotic grew slightly faster than the controls. By analysis of variance of the results of the first five treatments for which nine replicates were available, the difference between the means for antibiotics and no antibiotics was found significant at the $5 \%$ level. When each treatment difference was tested separately by the $t$ test, the only difference in gain that was significant at the $5 \%$ level was that between pigs receiving aureomycin mash (treatment 5 ) and controls (treatment $\mathrm{I}$ ). 
Table 2. Exp. x. Treatments, mean live-weight gain and efficiency of food utilization during 18 weeks. Pigs aged $12-14$ weeks at the beginning of the experiment. (Experiment began $\mathrm{I} 7$. vii. 50)

\begin{tabular}{|c|c|c|c|c|c|c|c|}
\hline \multirow{2}{*}{\multicolumn{2}{|c|}{ Treatment }} & \multirow[b]{2}{*}{$\begin{array}{c}\text { No. of } \\
\text { pigs }\end{array}$} & \multicolumn{2}{|c|}{ Weight } & \multicolumn{2}{|c|}{ Gain } & \multirow{2}{*}{$\begin{array}{l}\text { Food } \\
\text { consumed/ } \\
\text { lb. gain } \\
\text { (lb.) }\end{array}$} \\
\hline & & & $\begin{array}{c}\text { Initial } \\
\text { (lb.) }\end{array}$ & $\begin{array}{c}\text { Final } \\
\text { (lb.) }\end{array}$ & $\begin{array}{l}\text { Total } \\
\text { (lb.) }\end{array}$ & $\begin{array}{c}\text { Daily } \\
\text { (lb.) }\end{array}$ & \\
\hline I & Diet A, control & 9 & $59^{\circ} \circ$ & $233 \cdot 6$ & $174 \cdot 6$ & $I \cdot 39$ & 3.66 \\
\hline 2 & $\begin{array}{l}\text { Diet A with } 12 \text { mg aureomycin } \\
\text { hydrochloride per lb. of diet }\end{array}$ & 9 & $59 \cdot 3$ & $242 \cdot 0$ & $182 \cdot 7$ & $1 \cdot 45$ & $3 \cdot 63$ \\
\hline 3 & $\begin{array}{l}\text { Diet A with } 12 \mathrm{mg} \text { penicillin* } \\
\text { per } \mathrm{lb} \text {. of diet }\end{array}$ & 9 & $59 \cdot 4$ & $237 \cdot 2$ & $177 \cdot 8$ & $I \cdot 4 I$ & $3 \cdot 70$ \\
\hline 4 & $\begin{array}{l}\text { Diet A with } 62.5 \mathrm{mg} \text { penicillin* } \\
\text { per } \mathrm{lb} \text {. of diet }\end{array}$ & 9 & $59^{\circ} 9$ & $24 I \cdot 3$ & $\mathrm{I} 8 \mathrm{I} \cdot 4$ & $I \cdot 44$ & 3.68 \\
\hline 5 & $\begin{array}{l}\text { Diet A with } \mathrm{r} 8 \mathrm{I} 4 \mathrm{mg} \text { aureomycin } \\
\text { mash } \uparrow \text { per } \mathrm{lb} \text {. of diet }\end{array}$ & 9 & $58 \cdot 7$ & $24 I \cdot 6$ & 182.9 & $r \cdot 45$ & 3.60 \\
\hline 6 & $\begin{array}{l}\text { Diet A with } 18 \text { r } 4 \text { mg strepto- } \\
\text { mycin residue } \ddagger \text { and } 12 \text { mg peni- } \\
\text { cillin* per lb. of diet }\end{array}$ & 5 & $59 \cdot 2$ & $237 \cdot 8$ & $178 \cdot 6$ & $I \cdot 42$ & $3 \cdot 60$ \\
\hline & S.E. $\oint$ & 一 & 一 & - & $\pm 2 \cdot 8_{3}$ & - & \pm 0.040 \\
\hline \multicolumn{8}{|c|}{$\begin{array}{l}\text { * Given as procaine penicillin. } \\
\dagger \text { Lederle APF-5 feeding supplement containing approximately } \mathrm{I} \cdot \mathrm{I} \mathrm{g} \text { aureomycin and } 3.5 \mathrm{mg} \\
\text { vitamin } \mathrm{B}_{12} / \mathrm{lb} \text {. }\end{array}$} \\
\hline
\end{tabular}

The results for efficiency of food utilization showed no definite trend, and none of the treatment differences was statistically significant $(P>0.05)$.

The differences in live-weight gain and efficiency of food utilization between the pigs that received penicillin and streptomycin residue and the corresponding control animals (five replicates) were not significant when tested by the $t$ test $(P>0.05)$.

Exp. 2. Table 3 gives the results. During the experiment several pigs developed a husky cough, a condition previously observed in our piggery and described by Braude (I947). This condition appears now to be similar to, if not identical with, that associated with virus pneumonia described by Betts (1952). (Recent work at this Institute (unpublished) carried out in collaboration with the Institute of Animal Pathology, Cambridge, indicated that on a good diet containing ro \% fish meal, the addition of procaine penicillin or Aurofac 2A (Lederle Laboratories Inc.) had no effect on the pneumonia lesions or growth rate of badly coughing pigs.) In this test six pigs were affected, three on treatment $\mathrm{I}$ and one each on treatments 2,4 and 6 . When 19-22 weeks of age, these pigs went off their food and their gain in weight during this period was adversely affected. The condition was, however, relieved by subcutaneous injection of sulphathiazole (Soluthiazole, May \& Baker) (cf. Braude, 1947), and the setback was of a temporary nature only. However, its occurrence in three out of the six pigs on treatment $I$, in conjunction with the nutritionally suboptimal diet they were receiving, probably contributed to the poor mean growth rate of the pigs on this treatment.

In the course of the experiment one pig on treatment 2 dislocated a leg joint, and one pig on treatment 5 was found to be a hermaphrodite. The results for these two 
pigs have been omitted from Table 3 , and values obtained by the missing plot technique (Yates, 1933) for treatments $2-6$ were substituted.

The figures in Table 3 indicate that the addition of antibiotics to the vegetableprotein diet resulted in a marked improvement in both growth rate and efficiency of food utilization. Statistical comparison by the paired $t$ test of the results for the pigs that received antibiotics with those for pigs receiving the unsupplemented vegetable-

Table 3. Exp. 2. Treatments, mean live-weight gain and efficiency of food utilization during 18 weeks. Pigs aged 9-I I weeks at the beginning of the experiment. (Experiment began 25. vi. 5I)

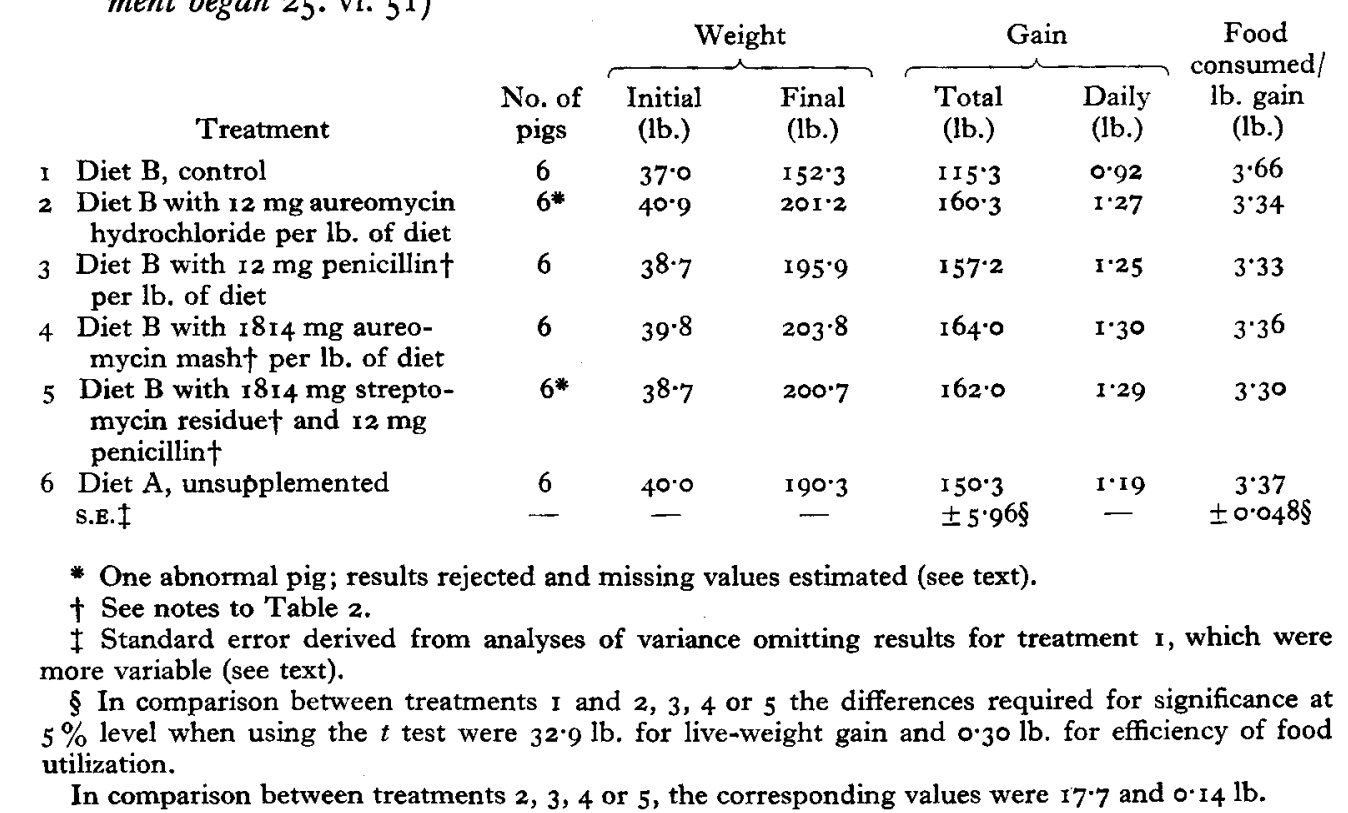

protein diet (treatments 2-5 with treatment $\mathrm{I}$ ) showed that mean differences in gain and efficiency of food utilization were significant at the $5 \%$ level. None of the mean differences between the four treatments (2-5) with an antibiotic supplement and treatment 6 with the unsupplemented fish-meal diet were significant $(P>0.05)$.

Exp. 3. Approximately 7-10 days after the beginning of the experiment nearly all the pigs not receiving penicillin in their diet (treatments $\mathrm{I}, 2$ and 3 ) became unthrifty and ceased to grow at a normal rate. The condition was characterized by poor appetite, some scouring and rough dirty coats. Blood and faecal samples from a number of these pigs were examined for presence of organisms of the salmonella group and the faeces for the presence of parasites, but with negative results. One pig on treatment 3 lost weight rapidly and was killed after 4 weeks on experiment. The post-mortem examination revealed necrotic enteritis and acute gastritis. Routine culture examination failed to reveal the presence of any pathogens. About 5 weeks after the condition first occurred a gradual improvement in the pigs became apparent, and by the end of a further 2 weeks all pigs seemed to have completely 
recovered. None of the pigs on treatments 4,5 and 6 receiving penicillin developed this condition, and all were normal throughout this period of the experiment.

When, 7 weeks after beginning the experiment, it became apparent that the husky cough condition, the same as that described in Exp. 2, was again affecting the pigs, all the pigs were treated with the sulphonamide drug. Eight of the pigs, three on treatment 4 and one on each of the other treatments, lost appetite and ceased to grow for a time when about $19-22$ weeks of age. At the same time a second pig on

Table 4. Exp. 3. Treatments, mean live-weight gain and efficiency of food utilization of pigs during the fattening period from 9-10 weeks of age to standard bacon weight. (Experiment began 29. i. 52)

\begin{tabular}{|c|c|c|c|c|c|c|}
\hline \multirow[b]{2}{*}{ Treatment } & \multirow[b]{2}{*}{$\begin{array}{l}\text { No. of } \\
\text { pigs }\end{array}$} & \multicolumn{2}{|c|}{ Weight } & \multirow{2}{*}{$\begin{array}{l}\text { No. of } \\
\text { days on } \\
\text { experiment }\end{array}$} & \multirow{2}{*}{$\begin{array}{l}\text { Daily } \\
\text { gain } \\
\text { (lb.) }\end{array}$} & \multirow{2}{*}{$\begin{array}{l}\text { Food } \\
\text { consumed } \\
\text { lb. gain } \\
\text { (lb.) }\end{array}$} \\
\hline & & $\begin{array}{c}\text { Initial } \\
\text { (lb.) }\end{array}$ & $\begin{array}{l}\text { Final } \\
\text { (lb.) }\end{array}$ & & & \\
\hline I Diet A & 6 & $37^{\circ} 0$ & $214 \cdot 8$ & $163 \cdot 8$ & I. IO & 3.74 \\
\hline 2 Diet $B$ & 6 & $36 \cdot 8$ & $216 \cdot 3$ & 160.5 & $I \cdot 12$ & $3 \cdot 64$ \\
\hline 3 Diet C & $6 *$ & 35.7 & 213.5 & $164 \cdot 6$ & 1.08 & 3.71 \\
\hline $\begin{array}{l}\text { Diet } A \text { with I } 2 \mathrm{mg} \text { penicillint } \\
\text { per } \mathrm{lb} \text {. of diet }\end{array}$ & 6 & $37 \cdot 2$ & $216 \cdot 2$ & $\mathrm{I} 45.3$ & $\mathrm{I} \cdot 24$ & 3.42 \\
\hline $\begin{array}{l}5 \text { Diet } \mathrm{B} \text { with } 12 \mathrm{mg} \text { penicillint } \\
\text { per } \mathrm{lb} \text {. of diet }\end{array}$ & 6* & $37 \cdot 5$ & 214.5 & $148 \cdot 0$ & $I \cdot 20$ & $3 \cdot 53$ \\
\hline $\begin{array}{l}6 \text { Diet } \mathrm{C} \text { with } 12 \mathrm{mg} \text { penicillint } \\
\text { per } \mathrm{lb} \text {. of diet }\end{array}$ & $6^{*}$ & $37 \cdot 8$ & $216 \cdot 3$ & $146 \cdot 3$ & $1 \cdot 22$ & 3.52 \\
\hline S.E. & - & 一 & - & - & $\pm 0.037 t$ & $\pm 0.087 \ddagger$ \\
\hline
\end{tabular}

* One pig abnormal or died; results rejected and missing values estimated (see text).

$\uparrow$ Given as procaine penicillin.

$\mp$ Differences in mean daily live-weight gain required for significance by the $t$ test were $0.108 \mathrm{lb}$. at the $5 \%$ level and $0.147 \mathrm{lb}$. at the I \% level. The corresponding values for efficiency of food utilization were 0.256 and $0.348 \mathrm{lb}$.

treatment 5 died; extensive and active pneumonia lesions in the lungs were found on post-mortem examination. Later one pig on treatment 6 became very lame and had to be taken off the experiment. Values obtained by the missing plot technique (Yates, 1933) were substituted in the analysis of the results.

In Table 4 the results are summarized for daily live-weight gain and efficiency of food utilization. It will be noted that in this experiment the pigs were kept on test until each reached a live weight of approximately $215 \mathrm{lb}$. and that in one of the columns in Table 4 the mean numbers of days on experiment are recorded for each treatment. The figures show that the addition of penicillin to each of the three meal mixtures resulted in a marked improvement in both growth rate and efficiency of food utilization of the pigs. The differences between means for penicillin and no penicillin were significant at the $0 \cdot \mathrm{I}$ and $\mathrm{I} \cdot 0 \%$ levels respectively.

The small differences between the means for the three diets not supplemented with penicillin can possibly be explained by the illness of the pigs receiving these diets during the first quarter of the experimental period.

Exp. 4. Two weeks after the beginning of the experiment one pig on treatment 2 was found to have a protruding rectum and was excluded from the experiment. Values calculated by the missing plot technique (Yates, 1933) were substituted in the analysis of the results. 
Once again the pigs were worried by cough and were treated with the sulphonamide drug. Seven of the pigs, two on each of treatments 1,2 and 6 and one on treatment 4 , lost appetite and grew subnormally for a short time when about 19-22 weeks of age.

Table 5. Exp. 4. Treatments, mean live-weight gain, efficiency of food utilization and total consumption of fodder per pig during $\mathrm{I} 28$ days. Pigs aged IO-I I weeks at the beginning of the experiment. (Experiment began 10. iii. 1952)

\begin{tabular}{|c|c|c|c|c|c|c|c|}
\hline \multirow[b]{2}{*}{ Treatment } & \multirow[b]{2}{*}{$\begin{array}{l}\text { No. of } \\
\text { pigs }\end{array}$} & \multicolumn{2}{|c|}{ Weight } & \multicolumn{2}{|c|}{ Gain } & \multirow{2}{*}{$\begin{array}{l}\text { Food } \\
\text { consumed*/ } \\
\text { lb. gain } \\
\text { (lb.) }\end{array}$} & \multirow{2}{*}{$\begin{array}{c}\text { Total } \\
\text { consumption } \\
\text { of fodder beet } \\
\text { (lb.) }\end{array}$} \\
\hline & & $\begin{array}{l}\text { Initial } \\
\text { (lb.) }\end{array}$ & $\begin{array}{c}\text { Final } \\
\text { (lb.) }\end{array}$ & $\begin{array}{l}\text { Total } \\
\text { (lb.) }\end{array}$ & $\begin{array}{r}\text { Daily } \\
\text { (lb.) }\end{array}$ & & \\
\hline ontrol & 6 & $43 \cdot 2$ & $176 \cdot 0$ & $132 \cdot 8$ & $1 \cdot 04$ & 4.19 & $1003 \cdot 2$ \\
\hline ontrol & 6 & $43 \cdot 2$ & $167 \cdot 4$ & $124 \cdot 2$ & 0.97 & $4 \cdot 28$ & 866.0 \\
\hline $\begin{array}{l}\text { with procaine } \\
\text { lint }\end{array}$ & 6 & $44^{\circ} \circ$ & $18 \times 3$ & $137 \cdot 3$ & 1.07 & $4^{\cdot 13}$ & $1025^{\circ}$ \\
\hline $\begin{array}{l}\text { with procaine } \\
\text { illin } t \text { and vitamin } B_{12} \ddagger\end{array}$ & 6 & $44^{\circ} 3$ & $174: 3$ & 130.0 & $I \cdot O I$ & $4 \cdot 3 I$ & $974 \cdot 8$ \\
\hline $\begin{array}{l}\text { with procaine } \\
\text { illint }\end{array}$ & 6 & $45^{\circ} 0$ & 199.2 & $154 \cdot 2$ & $1 \cdot 20$ & $4 \cdot 12$ & $133 I=0$ \\
\hline ith Aurofac 2 A $† \S$ & $\underline{-}$ & $43 \cdot 7$ & $188 \cdot 0$ & $\begin{array}{l}144 \cdot 3 \\
\pm 4 \cdot 31\end{array}$ & $\underline{1 \cdot 13}$ & $\begin{aligned} & 4.08 \\
\pm & 0.0899\end{aligned}$ & $\begin{array}{l}1112 \cdot 0 \\
\pm 78 \cdot 53^{* *}\end{array}$ \\
\hline
\end{tabular}

I Diet $\mathrm{D}$, control

2 Diet $\mathrm{E}$, control

3 Diet $E$ with procaine penicillin $\uparrow$

4 Diet $E$ with procaine penicillint and vitamin $B_{12} t$

5 Diet $\mathrm{D}$ with procaine penicillint

6 Diet $D$ with Aurofac $2 \mathrm{~A} \uparrow \S$ S.E.

Meal and fodder beet calculated on the basis of $12 \%$ moisture.

$\uparrow$ The amounts of the supplements added to the basal meals were adjusted approximately every 6 weeks in such a way that the actual intake of the supplements was approximately equivalent to that which the pigs would have obtained if they had been fed entirely on meal containing the following levels per ton of meal:

$\begin{array}{lr}\text { Procaine penicillin } & 14 \mathrm{~g} \\ \text { Aurofac 2A } & 1270 \mathrm{~g} \\ \text { Vitamin } \mathrm{B}_{12} \text { concentrate } & 10 \mathrm{~g}\end{array}$

$\ddagger$ The vitamin $B_{12}$ concentrate was in the form of the triturate and was mixed into a mannitol base to supply I $\mathrm{mg}$ vitamin $\mathrm{B}_{12} / \mathrm{g}$.

$\S$ The Aurofac $2 \mathrm{~A}$ was the Lederle aureomycin fermentation feeding supplement containing $3.6 \mathrm{~g}$ of aureomycin per $1 \mathrm{~b}$.

II Difference between means required for significance in a $t$ test was $12.57 \mathrm{lb}$. at $5 \%, \mathrm{I} 7.03 \mathrm{lb}$. at I \% and $22.8 \mathrm{I} \mathrm{lb}$. at $0.1 \%$ levels.

9 Difference between means required for significance in a $t$ test was $0.26 \mathrm{lb}$. at $5 \%$ level.

** Difference between means required for significance in a $t$ test was $229.2 \mathrm{lb}$. at $5 \%, 310.6 \mathrm{lb}$. at I \% and $415.9 \mathrm{lb}$. at $0.1 \%$ levels.

In Table 5 the mean figures are given for live-weight gain and efficiency of food utilization: the mean total consumptions of fodder beet by the pigs on each of the six treatments are also given. The figures indicate that the addition of penicillin alone to the two basal diets, and of Aurofac 2A to the basal meal D, resulted in a significant increase in rate of growth. The improvement was greater for the pigs receiving basal meal D, containing $2.5 \%$ fish meal, than for those receiving basal meal E consisting entirely of food of vegetable origin.

Although the mean figures suggest that the supplementation of the diets with antibiotics resulted in a slightly more efficient utilization of food, none of the treatment differences was significant. This is reflected in the figures for total consumption of fodder beet, which show that in each instance the addition of antibiotics to the diet resulted in an increase in the quantity of fodder beet consumed; this was, however, significant at the I \% level only for treatment 5 . 


\section{Effect of antibiotics on carcass quality}

The carcasses of the pigs from Exp. 2 were subjected to a detailed study. We were fortunate to obtain the co-operation of $\mathrm{Mr} \mathrm{J}$. K. Walley and $\mathrm{MrW}$. T. Gatherum of the Low Temperature Research Station, Cambridge, who also examined the effect of feeding antibiotics on the bacon-curing processes. A mass of data was collected and it is intended to communicate them separately. Measurements of carcass length, of inner and outer shoulder and loin fats and of rump and belly fats at three different points were taken on both sides of each carcass, and again on green and on smoked bacon. One smoked side from each pig was cut and measurements of the eye muscle were made. In general the procedure described by McMeekan (1940) was followed. Samples of fat were collected from five depots (inner and outer shoulder, inner and outer loin and kidney fat), and analysed for percentage of water, fat and fat-free residue. The iodine values of all the fat samples were also determined. In addition, grading marks were allocated for the major characteristics of the carcasses, including colour and firmness of the fat.

Although considerable variation was encountered in carcasses from pigs fed on the same diets, the results indicated that the feeding of antibiotics had no effect on the features investigated.

In Exp. 2 the pigs were killed at the same age, independently of their weights at the time of slaughter, whereas the pigs in Exp. 3 were all killed at about the same weight. The measurements enumerated above were also taken in Exp. 3, but on fresh carcasses only, and no fat analysis was carried out. As far as can be judged from the limited number of pigs, some of the differences encountered were due to the difference in the composition of the diets, rather than to the use of antibiotics.

Besides the taking of carcass measurements, the bacon sides were graded by an expert commercial grader. By the 1939 Contract Grading Scheme as the basis of assessment the carcasses were found to be, in general, of reasonably high standard, with the large majority attaining grade A, irrespective of the treatment received.

In Exp. 4, we limited our carcass investigation to measuring and grading the carcasses of pigs on treatments 5 and 6 , which gave the highest response to the antibiotic supplementation. Again most of the carcasses attained grade A by the 1939 grading procedure.

\section{Excretion of antibiotics in faeces and urine}

In Exp. I a single sample of faeces and urine from either one or two pigs on each of the experimental treatments was taken during the course of the experiment and was assayed for antibiotic activity. Penicillin was estimated by bio-assay on plates (British Pharmacopoeia, 1948a) using Staphylococcus aureus as the test organism at $\mathrm{pH} 7 \cdot 0$. Aureomycin was assayed as for streptomycin (British Pharmacopoeia, $\mathrm{r} 948 \mathrm{~b}$ ) using Bacillus subtilis as the test organism at $\mathrm{pH} 6 \cdot 0$. Similar samples of faeces were also assayed for their vitamin $B_{12}$ content. The tests were carried out on an aqueous extract prepared by boiling the sample for $10 \mathrm{~min}$ at $\mathrm{pH} 5$ in aqueous suspension in the presence of $0.01 \%$ cyanide. The aqueous extract was then assayed 
by the technique of Bessel, Harrison \& Lees (1950) and Harrison, Lees \& Wood (195I).

The antibiotic activity of the samples of faeces and urine was, with one exception, slight. In the wet faeces less than $\mathrm{I} \mu \mathrm{g}$ procaine penicillin/g or $\mathrm{I} \cdot 2 \mu \mathrm{g}$ aureomycin/g, and in urine less than $2 \mu \mathrm{g}$ procaine penicillin $/ \mathrm{ml}$. or less than $3.0 \mu \mathrm{g}$ aureomycin $/ \mathrm{ml}$. was detected. However, in one sample of urine from a pig receiving the high level of penicillin in the diet, $10.8 \mu \mathrm{g}$ procaine penicillin $/ \mathrm{ml}$. were detected.

The vitamin $B_{12}$ content of the wet faeces ranged from 0.3 to $1 \cdot 7 \mu \mathrm{g} / \mathrm{g}$, but no treatment differences were apparent.

\section{Antibiotics in the intestinal tract}

Samples of contents from the stomach, duodenum, caecum and colon from the pigs on treatments 2 and 4 in Exp. 2 were assayed for their aureomycin and penicillin activity respectively by the plate bio-assay mentioned on p. 313 . These samples were also assayed for penicillin activity by the cylinder-plate method with Streptococcus agalactiae as the test organism and inoculating without preliminary diffusion.

In Table 6 the results of the aureomycin and penicillin assays on the intestinal samples are given. These figures indicate that all samples except those from the colon contained an appreciable amount of aureomycin. For penicillin a fairly high activity for Staph. aureus was found in the duodenal samples, whereas with Strep. agalactiae only slight activity in all samples was indicated. The discrepancies in these results are probably due to the use of a different test organism and a different medium. It is not possible to be certain that the results of a single assay are, in fact, due to the antibiotic administered. Berridge \& Barrett (1952), for example, have observed a variety of inhibitory and stimulatory effects in the contents of chicken guts.

Table 6. Exp. 2. Mean penicillin and aureomycin activities per $g$ wet material in intestinal samples from three pigs on treatments 2 and 4

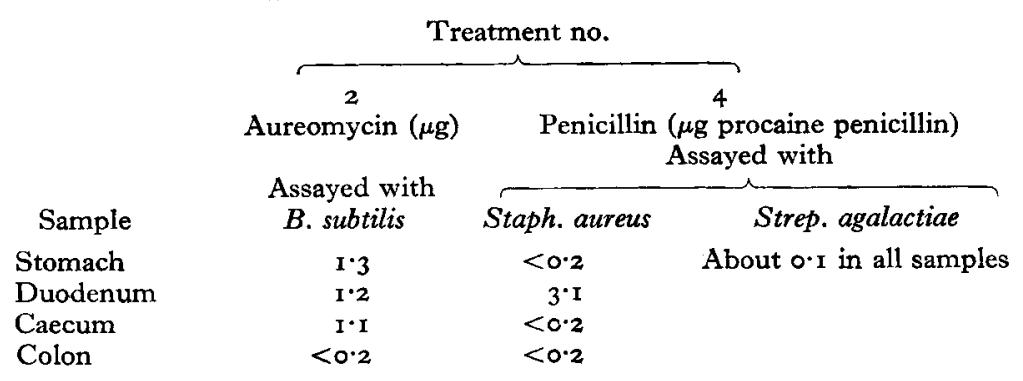

\section{Bacteriological examination of intestinal contents}

In Exp. 2 samples were taken after slaughter of contents from the stomach, duodenum, caecum and colon of three pigs on each of the six treatments.

Total microscopic counts and coliform and anaerobic counts were made on all samples except those from the stomach.

The microscopic counts were made on samples, preserved in formalin solution, by a modification of the Nigrosin method of Gall, Stark \& Loosli (1947). Anaerobic 
counts were made by a diluted count technique with inoculation into reinforced clostridium medium and coliform counts by a similar dilution method with McConkey broth. Counts were made on fresh caecal samples; the duodenal and colon samples were stored for a short period at $-20^{\circ}$ before the counts were made.

The results of the total microscopic counts on the intestinal samples gave slight indication that the addition of either aureomycin or aureomycin mash to the pig's diet resulted in small increases in the numbers of organisms present. No apparent differences in anaerobic or coliform counts were observed except for high anaerobic counts in the caecal samples of all three pigs that received procaine penicillin in the diet. The large variations in viable counts within any one group preclude a satisfactory interpretation of these results.

Vitamin $B_{12}$ activity in the intestinal tract

Samples of contents from the stomach, duodenum, caecum and colon from one pig on each of the six treatments in Exp. 2 were assayed for vitamin $B_{12}$ activity, after storage at $-20^{\circ}$, with Bacterium coli as the test organism, as described by Ford (I952).

The results of the vitamin $B_{12}$ assays are given in Table 7 . No marked treatment differences are apparent, but the figures indicate that appreciable intestinal synthesis of vitamin $\mathrm{B}_{12}$ activity occurred between the duodenum and caecum in all the pigs.

Table 7. Exp. 2. Vitamin $B_{12}$ activity ( $\mu g / g$ wet material) in intestinal samples taken from one pig on each of the six experimental treatments

\begin{tabular}{|c|c|c|c|c|c|c|}
\hline \multirow[b]{2}{*}{ Sample } & \multicolumn{6}{|c|}{ Treatment no. } \\
\hline & I & 2 & 3 & 4 & 5 & 6 \\
\hline Stomach & 0.10 & 0.10 & 0.10 & $0 \cdot 10$ & 0.30 & 0.03 \\
\hline Duodenum & 0.04 & 0.01 & 0.01 & 0.02 & 0.01 & 0.01 \\
\hline Caecum & 0.3 & 0.5 & 0.2 & 0.6 & 0.4 & 0.3 \\
\hline Colon & 0.8 & 0.3 & 0.5 & 0.3 & $0 . \dot{6}$ & 0.5 \\
\hline
\end{tabular}

\section{Storage of vitamin $B_{12}$ and vitamin $A$ in liver}

At slaughter the livers of all pigs in Exp. 2, with the exception of three pigs on treatment $I$, were removed, and the contents of vitamin $B_{12}$ and of vitamin $A$ in the fresh liver were determined. Vitamin $\mathrm{B}_{12}$ assays were made with Lactobacillus leichmannii as the test organism (Ford, I952), and the vitamin A content was determined by the method of Thompson, Ganguly \& Kon (1949).

In Table 8 the mean results are shown. It is seen that the liver stores of vitamin $B_{12}$ were markedly higher in the pigs given the supplements containing the vitamin (treatments 4 and 5) than in the other four groups of pigs. The highest liver stores of vitamin A were found in the pigs given aureomycin (treatments 2 and 4), either with or without supplementary vitamin $B_{12}$. In this connexion it is of interest that Burgess, Gluck, Brisson \& Laughland (r95 I) reported chicks responding to dietary penicillin to have had higher liver reserves of vitamin A, a finding later confirmed by Coates, 
Harrison, Kon, Porter \& Thompson (1952). In the present experiment, however, penicillin, although accelerating the growth of the pigs, did not increase the vitamin A reserves in their livers.

Table 8. Exp. 2. Mean vitamin $B_{12}$ activity and vitamin $A$ content of the livers of pigs on the six experimental treatments

\begin{tabular}{|c|c|c|c|c|c|}
\hline \multirow{2}{*}{$\begin{array}{c}\text { Treatment } \\
\text { no. }\end{array}$} & \multirow{2}{*}{$\begin{array}{l}\text { No. of } \\
\text { pigs }\end{array}$} & \multicolumn{2}{|c|}{ Vitamin $\mathrm{B}_{12}$ activity } & \multicolumn{2}{|c|}{ Vitamin A } \\
\hline & & $\mu \mathrm{g} / \mathrm{g}$ & $\mu \mathrm{g} /$ liver & i.u. $/ g$ & i.u./liver \\
\hline$I$ & 3 & 0.069 & I34 & 1 $2 \cdot 8$ & 24,477 \\
\hline 2 & 5 & 0.084 & 152 & $19 \cdot 3$ & 34,877 \\
\hline 3 & 6 & 0.043 & 107 & $13 \cdot 1$ & $24,74 \mathrm{I}$ \\
\hline 4 & 6 & 0.204 & 353 & 19.6 & 33,722 \\
\hline $\begin{array}{l}5 \\
6\end{array}$ & $\begin{array}{l}5 \\
6\end{array}$ & $\begin{array}{l}0.401 \\
0.064\end{array}$ & 720 & $\begin{array}{l}13.2 \\
15.1\end{array}$ & $\begin{array}{l}22,342 \\
26,830\end{array}$ \\
\hline
\end{tabular}

Stability of penicillin in meal mixtures

To gauge the adequacy of the mixing methods used, and also to determine whether there was any loss of penicillin activity in the mixed meals during sack storage in the piggery, samples of each of the three mixtures used in Exp. 3, containing procaine penicillin, were assayed for antibiotic activity immediately after mixing, after 3 weeks' storage and after 6 weeks' storage.

The results given in Table 9 indicate, when allowance is made for the errors unavoidable in assays of this type, that the methods used for mixing the small quantities of penicillin into the meal were satisfactory, and that little or no loss in potency occurred during 6 weeks' storage.

Table 9. Exp. 3. Mean penicillin activity (mg/lb.) of meal mixtures

$\begin{array}{cccc}\begin{array}{c}\text { Mixture } \\ \text { no. }\end{array} & \begin{array}{c}\text { Immediately } \\ \text { after mixing }\end{array} & \begin{array}{c}\text { After storage } \\ \text { for } 3 \text { weeks }\end{array} & \begin{array}{c}\text { After storage } \\ \text { for } 6 \text { weeks }\end{array} \\ \text { I } & 13.0 & 12.6 & 13.2 \\ 2 & 13.2 & 12.7 & 10.8 \\ 3 & 15.5 & 10.7 & 15.1\end{array}$

DISCUSSION

These experiments provide a few pointers to the value of antibiotics under conditions of feeding and management prevailing in this country.

In Exps. I and 2 aureomycin and penicillin added at the level of $12 \mathrm{mg} / \mathrm{lb}$. diet stimulated growth and improved efficiency of food utilization on either all-vegetable or mixed-protein diets, the latter containing white fish meal.

The response on diets containing the animal protein (Exp. I) was smaller than that on the all-vegetable rations (Exp. 2). One should, however, bear in mind that in Exp. I the pigs receiving the different treatments were kept in the same pen. As, later, the antibiotics were found in the excreta of the pigs, it may be that the control pigs in this test obtained small quantities of antibiotics from the floor of the pen and that this reduced the difference between the treatments.

The observations with the Lehmann system are of interest, as this type of diet 
utilizes a large proportion of home-grown bulky foods. The results showed a marked improvement from the addition of antibiotics to the two diets tested, and it is noteworthy that the presence of as little as $2.5 \%$ of fish meal in the basal diet resulted in greater enhancement from the antibiotics than when the basal diet was of vegetable origin only. It is thus obvious that particular care is needed in comparing the response to antibiotics on diets differing in quality of protein. It is also possible that other factors than protein in products like fish meal may play a part. In Exp. 3 there occurred some intercurrent unthriftiness of a type not infrequent in commercial pig rearing; this illustrates a possible additional value of antibiotics added primarily as promoters of growth. The pigs given the antibiotic did not apparently suffer the same setback as the control animals, irrespective of the kind of diet they received.

Taken as a whole, our experiments did not show any consistent difference between the growth-promoting effects of aureomycin and penicillin.

The experiment in which two levels of penicillin were used suggested that no great benefit was derived from a markedly increased dose of antibiotic.

We are not in a position to discuss the economic aspects of supplementing feeds with antibiotics. Our results support the opinion of many workers that the response is variable and depends on many factors. Nevertheless we are satisfied that their addition, under many conditions at any rate, leads to more rapid growth and to a slight but significant improvement in the efficiency of food utilization.

No indication of the way in which antibiotics act was obtained from our experiments. We could demonstrate the presence of the antibiotic throughout the gut of the pig and in the faeces, but attempts to detect differences in bacterial flora failed.

It was obvious that present-day bacteriological methods available for the study of intestinal flora are not satisfactory for quantitative assessment of any changes that could be attributed to the effect of antibiotics.

The growth-promoting effect of the antibiotics was observed on diets containing vitamin $B_{12}$ and on diets free of this vitamin. In this connexion it should be noted that the synthesis of vitamin $B_{12}$ activity in the intestines was in no way affected by the antibiotics fed to the animals.

The carcass quality of the pigs receiving the antibiotics was in no way affected by the treatment.

\section{SUMMARY}

I. Four experiments are described involving 125 individually fed fattening pigs whose diets were supplemented with aureomycin, penicillin, or aureomycin residues.

2. In the first experiment the addition of antibiotics to a diet containing adequate animal protein resulted in only a comparatively small improvement in the rate of gain of the pigs. Possible reasons for this result are discussed.

3. In the second experiment antibiotic supplementation of a diet containing only vegetable proteins resulted in a marked improvement in both the live-weight gain and efficiency of food utilization of the pigs. The performance of the pigs receiving the supplemented vegetable-protein diets was similar to that of pigs fed on an unsupplemented diet containing 10 $\%$ of white fish meal. 
4. In the third experiment, irrespective of the presence or absence of animal protein in the diet, penicillin supplementation prevented the depression of normal growth due to an unspecified disease that affected the control pigs.

5. In the fourth experiment, the rate of gain and total consumption of food of pigs fed on the Lehmann system (with fodder beet as the bulky supplementary food) was increased by the addition of antibiotics either to a basal meal containing vegetable proteins only or to a basal meal in which $2.5 \%$ of white fish meal was included. The inclusion of the $2.5 \%$ of fish meal in the diet increased the response to antibiotic supplementation.

6. The addition of antibiotics to the diet had no significant effect on carcass quality.

7. The antibiotics appeared to have no effect on the virus pneumonia from which some of the pigs suffered.

8. Appreciable intestinal synthesis of vitamin $B_{12}$ activity occurred between the duodenum and caecum in all the pigs.

9. Brief observations are recorded on the amounts of antibiotic in the intestinal contents and urine of the treated pigs. The bacterial examination of intestinal contents yielded no definite information. Results are presented on the effect of antibiotic feeding on storage of vitamins $A$ and $B_{12}$ in the liver and on the stability of procaine penicillin in meal mixtures.

We wish to thank our colleagues, Dr N. S. Berridge, Mr J. E. Ford, Dr S. Y. Thompson, Miss J. M. Willingale and Miss P. M. Clarke for estimating the antibiotics in the digestive tract, for estimating vitamin $B_{12}$ and vitamin $A$ in the liver, for bacteriological examination of the intestinal contents and for statistical advice, respectively. We also wish to thank Dr W. F. J. Cuthbertson and his colleagues from Glaxo Laboratories Ltd. for the assays of penicillin in meal mixture and estimation of vitamin $B_{12}$ in intestinal contents and Dr N. S. Barron for veterinary advice in connexion with Exp. 3. We are greatly indebted to Mr C. E. B. Brett of T. Wall \& Sons Ltd. for grading the carcasses from Exps. 3 and 4 ; to Mr J. K. Walley and Mr W. T. Gatherum, Low Temperature Research Station, Cambridge, for their collaboration in examining the carcasses from Exp. 2; to the Directors of M. Venner \& Sons Ltd., Bacon Curers, Reading, for the slaughter-house facilities and helpful co-operation. We acknowledge with thanks the gift of aureomycin, aureomycin residues and Aurofac received from Lederle Laboratories Inc. and of procaine penicillin and streptomycin residues from Glaxo Laboratories Ltd.

\section{REFERENCES}

Barber, R. S., Braude, R., Kon, S. K. \& Mitchell, K. G. (1952). Chem. E Ind. p. 713.

Berridge, N. J. \& Barrett, J. (I952). Biochem. J. 5I, iii.

Bessel, C. J., Harrison, E. \& Lees, K. A. (1950). Chem. E Ind. p. 56 r.

Betts, A. O. (1952). Vet. Rec. 64, 283.

Braude, R. (1947). Vet. Rec. 59, I65.

Braude, R., Kon, S. K. \& Mitchell, K. G. (195 I). Brit. F. Nutr. 5, viii.

Braude, R., Kon, S. K. \& Porter, J. W. G. (1953). Nutr. Abstr. Rev. 23, 47.

Braude, R. \& Mitchell, K. G. (1949-50). F. Minist. Agric. 56, 369.

Braude, R. \& Mitchell, K. G. (1950-1). F. Minist. Agric. 57, 501. 
Braude, R., Wallace, H. D. \& Cunha, T. J. (1953). Antibiot. Chemother. 3, 27 I.

British Pharmacopoeia (1948a). Appendix 15, p. 816.

British Pharmacopoeia (1948b). Addendum (195I), Appendix 15, p. 95.

Burgess, R. C., Gluck, M., Brisson, G. \& Laughland, D. H. (I95I). Arch. Biochem. Biophys. 33, 339.

Coates, M. E., Harrison, G. F., Kon, S. K., Porter, J. W. G. \& Thompson, S. Y. (1952). Chem. $\boldsymbol{\sigma}^{\circ}$ Ind. p. 149 .

Ford, J. E. (r952). Brit. 9. Nutr. 6, 324.

Gall, L. S., Stark, C. N. \& Loosli, J. K. (1947). F. Dairy Sci. 30, 891.

Harrison, E., Lees, K. A. \& Wood, F. (195I). Analyst, 76, 696.

McMeekan, C. P. (1940). 7. agric. Sci. 30, 387.

Stokstad, E. L. R., Jukes, T. H., Pierce, T., Page, A. C. Jr. \& Franklin, A. L. (1949). J. biol. Chem. 180, 647.

Thompson, S. Y., Ganguly, J. \& Kon, S. K. (1949). Brit. F. Nutr. 3, 50.

Woodman, H. E. \& Evans, R. E. (195I). F. agric. Sci. 4I, ro2.

Yates, F. (1933). Emp. Y. exp. Agric. 1, 129.

\title{
Vitamin $\mathrm{B}_{12}$-like Compounds
}

\section{Vitamin $B_{12}$ Activity for Chicks and for different Micro-organisms of Gut Contents and Faeces*}

\author{
BY M. E. COATES, J. E. FORD, G. F. HARRISON, S. K. KON \\ AND J. W. G. PORTER \\ National Institute for Research in Dairying, University of Reading
}

(Received I6 March 1953)

In studying the vitamin $B_{12}$ metabolism of the ruminant we were interested in comparing microbiological and chick measurements of vitamin $B_{12}$ in rumen contents and faeces, and this paper deals with the results of such comparisons.

It has been generally accepted that certain strains of Lactobacillus leichmannii, Bacterium coli and Euglena gracilis can be used for the measurement of vitamin $\mathrm{B}_{\mathbf{1 2}}$. For some time we have used Lb. leichmannii and Bact. coli for the routine assay of the vitamin in natural materials and have found broad similarity between results obtained with these two micro-organisms. The speed and simplicity of the Bact. coli plate assay made it useful for higher-potency materials, whereas the assay of less potent materials was more conveniently carried out in a tube assay with Lb. leichmannii. We have also used Euglena gracilis, believed to be more specific for vitamin $\mathrm{B}_{12}$ than other assay organisms.

There is increasing evidence that the chick assay of vitamin $B_{12}$ in natural materials is not specific for the vitamin, because it measures the whole 'animal protein factor' complex. The results, therefore, are not strictly comparable with those obtained by microbiological methods and tend on the whole to be markedly higher (Coates, Harrison \& Kon, 195I).

The application of both chick and microbiological methods to the measurement

* Read in part before the Biochemical Society (Coates, Ford, Harrison, Kon, Porter, Cuthbertson \& Pegler, 195I). 